DOI

\title{
ПОРІВНЯННЯ ЯКОСТІ ЖИТТЯ ЖІНОК ЗАКАРПАТТЯ ЗАЛЕЖНО ВІД ЕТНІЧНОГО ТА СОЦІАЛЬНОГО СТАТУСУ
}

\author{
ОІ. І. Кутчак, А. С. Долгіх, П. О. Колесник \\ ДВНЗ «Ужгородський національний університет»
}

\begin{abstract}
РЕЗЮМЕ. Метою дослідження було порівняння якості життя жінок ромської та інших національностей і оцінка впливу на показники якості життя віку, кількості дітей, шкідливих звичок, рівня освіти і достатку. Показники загальної якості життя та якості життя у сферах фізичного здоров'я та навколишнього середовища у жінок ромської національності у віці до 40 років статистично достовірно вищі, ніж у жінок інших національностей. Кількість дітей та шкідливі звички впливають на показники якості життя жінок, особливо жінок ромської національності. Для жінок інших національностей вік $\epsilon$ основним фактором, що впливає на психологічний і соціальний компонент якості життя.
\end{abstract}

КЛЮчОВІ СлОВА: якість життя, національність, кількість дітей.

Вступ. У сучасній медицині якість життя людини розглядають як інтегральну характеристику її стану, що складається з фізичного, психологічного, соціального компонентів. За допомогою цих компонентів можна визначити рівень життя окремої особи та цілих груп, встановити, який складник має позитивний або негативний вплив та на що треба вплинути, щоб покращити якість життя [1].

Всесвітня організація охорони здоров'я (ВООЗ) визначає якість життя як сприйняття людьми свого положення в житті залежно від культурних особливостей і системи цінностей та в зв'язку з їхніми цілями, очікуваннями, стандартами, турботами [2].

Проект «Якість життя» BOO3 (WHOQOL) був розпочатий у 1991 році. Його мета полягала в розробці міжнародного крос-культурного порівняльного інструменту для оцінки якості життя [3]. Опитувальник WHOQOL-BREF оцінює чотири галузі, пов'язані з якістю життя: фізичне здоров'я, психологічний стан, соціальні відносини і навколишнє середовище [4]. Кожна галузь включає ряд складових: фізичне здоров'я - симптоми захворювання, можливість виконання фізичної роботи, здатність до самообслуговування; психологічний стан - тривогу, депресію, ворожу поведінку; соціальні відносини - соціальну підтримку, роботу, громадські зв'язки тощо [1]. За допомогою цих компонентів можна визначити загальну якість життя і загальний стан здоров'я [4].

Закарпаття, як і багато європейських країн, $\epsilon$ домом для населення рома, яке належить до соціально незахищених груп. Населення, яке проживає в поселеннях рома, характеризується значно нижчими соціально-економічними стандартами, значно гіршими умовами життя, порівняно з більшістю [5]. Життя в поселеннях рома асоціюється з гіршим здоров'ям, порівняно з більшістю населення [6].
У більшості країн ряд медичних і соціальних факторів в сукупності зумовлюють більш низьку якість життя жінок. Нерівномірний доступ до інформації та основних медичних послуг ще більше посилює ризики для їх здоров'я [7].

Мета дослідження. Порівняння якості життя жінок ромської та інших національностей та оцінка впливу на показники якості життя віку, кількості дітей, шкідливих звичок, рівня освіти і достатку.

Матеріал і методи дослідження. Було оцінено якість життя 100 жінок: з них 21 жінка була ромської національності. Анкетування проводили за допомогою адаптованого та перекладеного українською мовою (Кутчак І. І., Долгіх А. С., Колесник П. О., 2016) опитувальника WHOQOL-BREF, запропонованого ВООЗ, що включає 26 питань. Визначали кореляційні зв'язки між якістю життя у різних сферах та віком жінки, кількістю дітей, шкідливими звичками, рівнем освіти і достатку. Статистичний аналіз даних проводили за допомогою пакета прикладних програм Statistica 8.0 (StatSoft, США).

Результати й обговорення. Середній вік жінок, яких опитували, становив $(33,54 \pm 9,53)$ роки. Середні показники якості життя по сферах для всіх обстежуваних жінок становили: у сфері фізичного здоров'я - $(46,3 \pm 12,8)$, психічного - $(64,0 \pm 13,7)$, соціального - $(70,6 \pm 16,5)$, навколишнього середовища - $(37,4 \pm 11,2)$. Загальна якість життя дорівнювала $(54,6 \pm 9,7)$.

Для всіх обстежених жінок характерний сла6кий прямий кореляційних зв'язок загальної якості життя з кількістю дітей і кількістю викурених сигарет за добу $-\mathrm{R}=0,247$ i $\mathrm{R}=0,262$ відповідно $(p<0,05)$. У жінок з низьким соціальним достатком кількість дітей і куріння мають найбільший вплив на загальну якість життя $(\mathrm{R}=0,738$ i $\mathrm{R}=0,776$ відповідно; $\mathrm{p}<0,05)$. На нашу думку, це виникає через 
Огляди літератури, оригінальні дослідження, погляд на проблему

переорієнтацію жінки зі своїх потреб на потреби дитини.

Відмічався прямий кореляційний зв'язок середньої сили між якістю життя у сфері фізичного здоров'я та навколишнього середовища з кількістю дітей ( $R=0,3029$ і $R=0,305$ відповідно; $p<0,05)$, кількістю викурених в день сигарет $(R=0,484$ i $\mathrm{R}=0,485$ відповідно; $\mathrm{p}<0,05)$ та слабкий $-з$ кількістю випитих чашок кави за добу $(R=0,228$ i $R=0,231$ відповідно; $\mathrm{p<0,05).} \mathrm{Можливо,} \mathrm{це} \mathrm{пов'язано} \mathrm{з} \mathrm{тим,}$ що шкідливі звички призводять до суб'єктивного покращення самопочуття жінок.

Для всіх жінок характерний слабкий обернений кореляційний зв'язок між психологічною та соціальною складовими якості життя та віком ( $R=-0,215$ і $R=-0,198$ відповідно; $\mathrm{p}<0,05)$. Вік най- більше впливає на психологічну складову якості життя небагатодітних жінок ( $R=-0,361, p<0,05)$, а соціальна складова найбільше погіршується з віком у жінок, які не мають дітей або мають одну дитину ( $R=-0,550 ; p<0,05)$. Скоріш за все, з подорослішанням дітей жінка знову починає акцентуватися на собі, а при відсутності дітей немає потреби в соціальній адаптації, що з віком зазвичай погіршується.

Було опитано 76 жінок віком до 40 років: 21 ромської, 55 - інших національностей. Показники загальної якості життя та якості життя у сферах фізичного здоров'я та навколишнього середовища у віці до 40 років у жінок ромської національності статистично достовірно вищі, ніж у жінок інших національностей такого ж віку, p<0,05 (рис. 1).

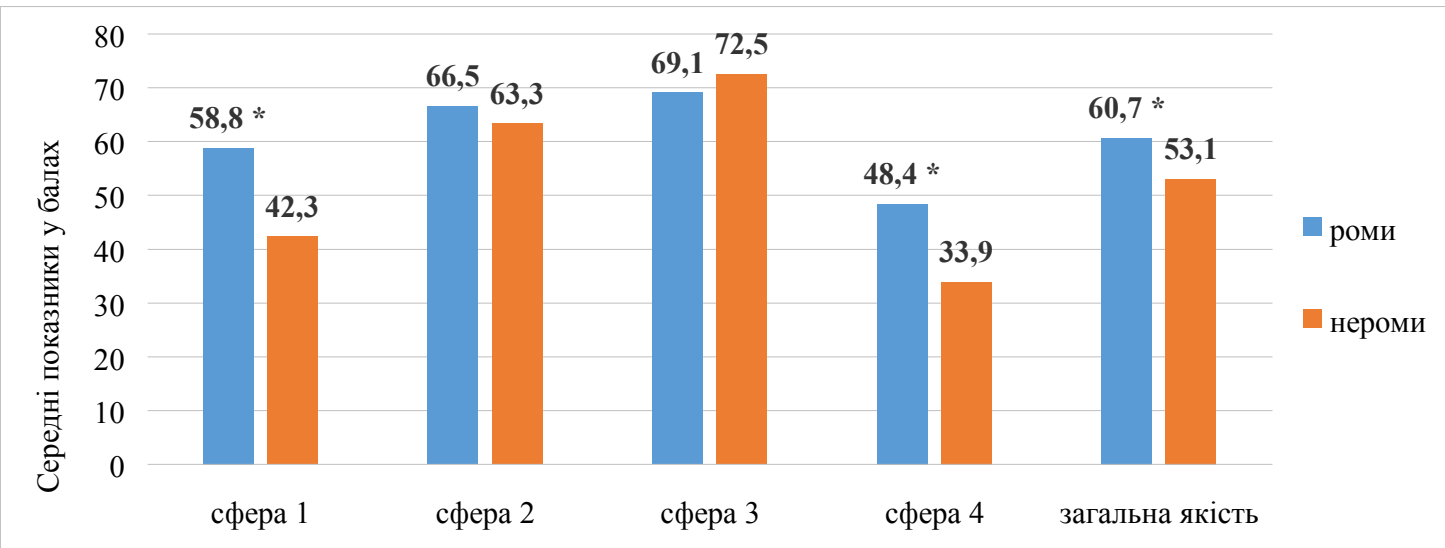

Якість життя

Примітка* - різниця статистично достовірна при порівнянні показників якості життя жінок ромської національності в порівнянні з жінками інших національностей $(p<0,05)$.

Рис. 1. Середні значення показників якості життя у жінок ромської на інших національностей у віці до 40 років.

У віці до 40 років кількість дітей та кількість викурених сигарет впливають на загальну якість життя ( $R=0,290$ i $R=0,267$ відповідно, $p<0,05)$, якість життя у сферах фізичного здоров'я $(\mathrm{R}=0,438 \mathrm{i}$ $\mathrm{R}=0,530$ відповідно, $\mathrm{p}<0,05)$ та навколишнього середовища ( $R=0,440$ і $R=0,531$ відповідно, $p<0,05)$ всіх жінок. Психологічний компонент якості життя у всіх обстежених жінок до 40 років погіршується з віком $(R=-0,236, p<0,05)$.

У жінок ромської національності загальна якість життя та якість життя у сферах фізичного здоров'я та навколишнього середовища статистично достовірно вища, ніж у жінок інших національностей такого ж віку $(Z=3,122 ; Z=-4,614$; $\mathrm{Z}=-4,631$ відповідно, $\mathrm{p}<0,05)$. Така ситуація може бути спричинена заниженим рівнем вимог до свого здоров'я та навколишнього середовища через неосвіченість більшості жінок ромської національності.
Для ромських жінок характерна пряма кореляційна залежність середньої сили якості життя у сферах фізичного здоров'я та навколишнього середовища від кількості дітей $(\mathrm{R}=0,492$ і $\mathrm{R}=0,492$ відповідно; $\mathrm{p}<0,05)$.

У небагатодітних жінок ромської національності соціальний компонент якості життя статистично достовірно гірший, ніж у небагатодітних жінок інших національностей $(Z=2,662, p<0,05)$. Можливо, більша кількість дітей примушує ромську жінку до сильнішої соціальної адаптації.

Було порівняно якість життя жінок неромської національності віком до 40 і після 40 років включно (рис. 2).

Для всіх жінок інших національностей характерна обернена залежність соціальної складової якості життя від віку жінки $(R=-0,228, p<0,05)$.

У жінок 40 років і старше між якістю життя у сфері фізичного здоров'я і навколишнього сере- 
Огляди літератури, оригінальні дослідження, погляд на проблему

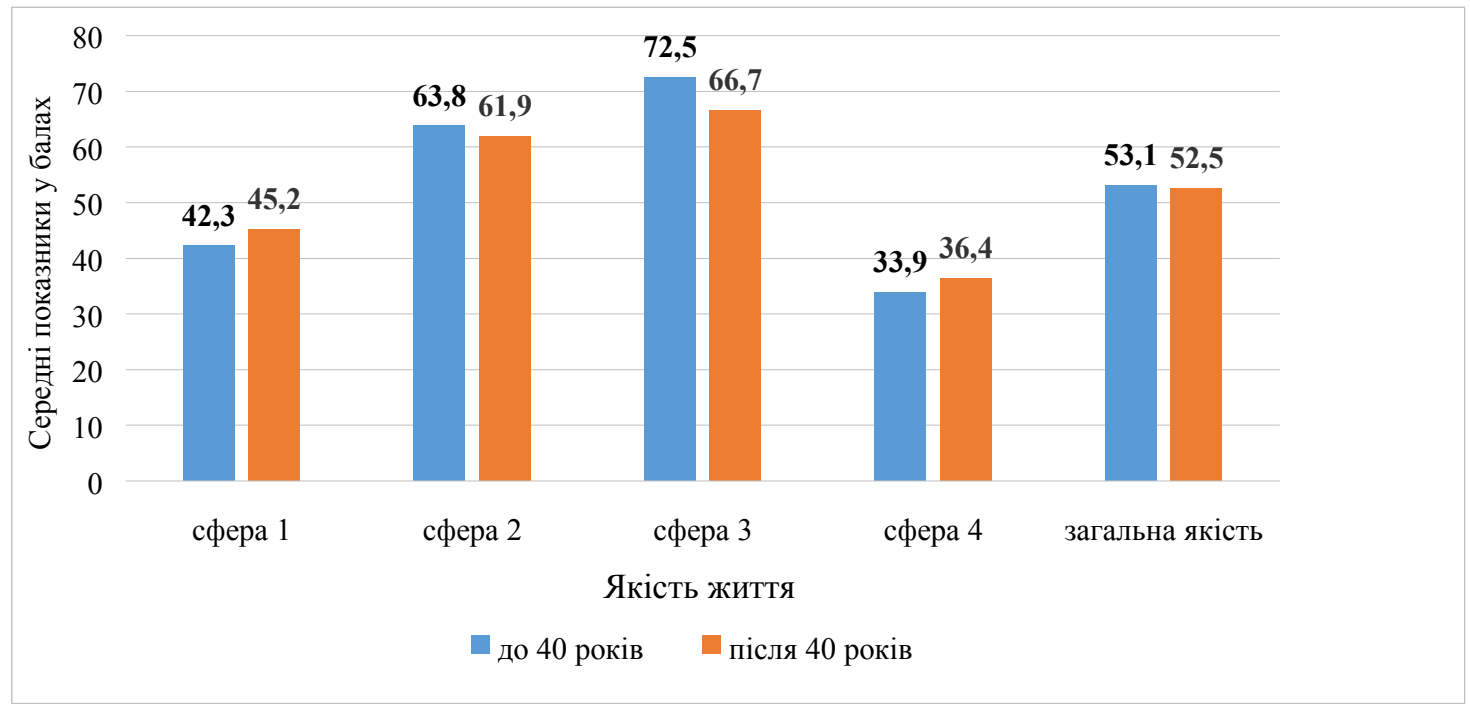

Рис. 2. Середні показники якості життя жінок інших національностей у віці до 40 років і старше 40 років.

довища з віком відмічається обернений кореляційний зв'язок середньої сили ( $R=-0,566$ i $R=-0,566$ відповідно, $\mathrm{p}<0,05)$.

Отже, для жінок неромської національності вік негативно впливає на соціальну якість життя, що, можливо, пов'язано з труднощами у пошуках роботи, а після 40 років здоров'я жінок погіршується.

Висновки. Показники загальної якості життя та якості життя у сферах фізичного здоров'я та навколишнього середовища у віці до 40 років у жінок ромської національності статистично достовірно вищі, ніж у жінок інших національностей такого ж віку.

1. Кількість дітей впливає на показники якості життя жінок, особливо у жінок ромської національності.

\section{ЛІТЕРАТУРА}

1. Ягенський А. В. Оцінка якості життя у сучасній медичній практиці / А. В. Ягенський, І. М. Січкарук [Електронний ресурс] // Журнал «ВнутріНшня медицина». 2007. - № 3 (3). - Режим доступу: http://www.mif-ua.com/ archive/article/418

2. Якість життя [Електронний ресурс] : матеріал 3 Вікіпедії. - Режим доступу: https://uk.wikipedia.org/wiki/ Якість_життя

3. WHO. Quality of Life-BREF (WHOQOL-BREF). Management of substance abuse - Режим доступу: http://www.who.int/substance_abuse/research_tools/ whoqolbref/en/

4. Development of the World Health Organization WHOQOL-BREF quality of life assessment // Psychol Med. - 1998. - № 28 (3). - P. 551-558.
2. Шкідливі звички, такі як куріння та вживання кави, підвищують загальну якість життя, а якісь життя у сфері фізичного здоров'я та навколишнього середовища також покращується зі збільшенням кількості викурених сигарет на добу.

3. У жінок з низьким соціальним статусом шкідливі звички є одним з основних факторів, що детермінують якість життя.

4. Для жінок неромської національності вік $\epsilon$ основним фактором, що впливає на психологічний і соціальний компоненти якості життя.

Перспективи подальших досліджень - оцінити вплив на якість життя різних захворювань.

5. Socioeconomic characteristics of the population living in Roma settlements and their association with health and health-related behaviour / A. M. Gecková, I. Babinská, D. Bobáková [et al.] / Cent. Eur. J. Public. Health. - 2014. № 22 -P. 57-64.

6. Do eating habits of the population living in Roma settlements differ from those of the majority population in Slovakia? / E. Hijová, A. M. Gecková, I. Babinská I. [et al.] / Cent. Eur. J. Public Health. - 2014. - № 22 - P. 65-68.

7. 10 facts about women's health [Електронний peсурc]: WHO site. - 2011. - Режим доступу: http://www. who.int/features/factfiles/women/en/. 
@I. I. Kutchak, A. S. Dolhikh, P. O. Kolesnyk

\section{Uzhhorod National University}

SUMMARY. The aim of study was to compare the quality of life of women of the Roma and other nationalities and assessment the impact of age, number of children, bad habits, level of education and wealth on the on the quality of life. Indicators of overall quality of life and quality of life in the areas of physical health and the environment of women under the age of 40 years were significantly higher in Roma, than in women of other nationalities. Number of children and bad habits affect the quality of life, especially in Roma women. For women of other nationalities, the age is a major factor that influences on psychological and social components of quality of life.

KEY WORDS: quality of life, ethnicity, number of children. 